\title{
Effects of temperature and fluid media on the scroll width size of the Descemet's membrane endothelial keratoplasty (DMEK) donor graft
}

This article was published in the following Dove Press journal:

Clinical Ophthalmology

I September 2017

Number of times this article has been viewed

\section{Ellen $\mathrm{H}$ Koo' \\ Allen O Eghrari ${ }^{2}$ \\ Ryan S Meshkin ${ }^{2}$ \\ Wei Shi' \\ William J Feuer' \\ Karen G DeMarco ${ }^{3}$ \\ Arthur C Kurz}

'Bascom Palmer Eye Institute, University of Miami Miller School of Medicine, Miami, FL, ${ }^{2}$ Wilmer Eye Institute, Johns Hopkins University School of Medicine, ${ }^{3}$ KeraLink International, Baltimore, MD, USA
Correspondence: Ellen H Koo Bascom Palmer Eye Institute, University of Miami Miller School of Medicine, 7I0I Fairway Dr, Palm Beach Gardens, FL 334I8, USA

Tel +I 56I 5I5 I544

Email exk126@med.miami.edu
Aim: Our study was conducted to evaluate whether higher temperature leads to increased - or wider - scroll widths of the Descemet's membrane endothelial keratoplasty (DMEK) donor graft. Purpose: To investigate the effects of temperature and fluid media on the DMEK donor graft scroll widths.

Materials and methods: This research work was a laboratory investigation. Baseline cell count was taken via specular microscopy for the donor corneas at room temperature $\left(20^{\circ} \mathrm{C}-25^{\circ} \mathrm{C}\right)$. The endothelium sides of the donor corneas were stained with Trypan Blue Solution $0.4 \%$ for $30 \mathrm{~s}$, and the Descemet's membranes were stripped. The DMEK donor grafts were placed into three different fluid media - Optisol ${ }^{\circledR}$, Balanced Salt Solution (BSS), and BSS PLUS ${ }^{\circledR}$ (BSS Plus). The DMEK donor grafts were then transferred into cold temperature $\left(4^{\circ} \mathrm{C}\right)$ for $60 \mathrm{~min}$, after which the donor grafts' scroll widths were examined and measured. The donor grafts were then warmed in the incubator and brought to physiological temperature $\left(35^{\circ} \mathrm{C}-37^{\circ} \mathrm{C}\right)$, and their scroll widths were examined and measured again.

Results: In 30 measurements of ten tissues across three temperature and fluid conditions, the average scroll width measured $1.73 \mathrm{~mm}$, ranging from 1.1 to $2.9 \mathrm{~mm}$. In a mixed linear model, the scroll widths increased with temperature $(P=0.02)$. There was no significant difference in scroll widths among the three solutions ( $P=0.84$, mixed linear model).

Conclusion: We observed an increase in DMEK donor graft scroll widths with higher temperatures. The usage of BSS Plus as media solution could also lead to smaller DMEK donor graft scroll widths, compared with BSS, but our study does not establish this.

Keywords: DMEK, graft scroll, graft conformation, DMEK scroll, DMEK graft

\section{Introduction}

In the treatment of endothelial dystrophy, endothelial keratoplasty (EK) has largely replaced penetrating keratoplasty $(\mathrm{PK}){ }^{1,3} \mathrm{EK}$ offers advantages of small incisional surgery, compared with PK - these include faster visual recovery, preservation of ocular structural integrity, and decreased overall induced astigmatism. ${ }^{2}$ By 2014 , Descemet stripping endothelial keratoplasty (DSEK) had become the most common (50\%) type of corneal transplantation technique performed in the United States. ${ }^{1}$

More recently, the Descemet's membrane endothelial keratoplasty (DMEK) procedure has gained attention as a treatment type of EK. This is due to better visual acuity results in the first year after the DMEK surgery, compared to that typically reported for DSEK. ${ }^{4}$ In addition, DMEK is associated with lesser refractive changes and similar endothelial cell counts when compared to DSEK. ${ }^{4}$ 
Despite these promising results, DSEK remains the most common EK procedure. ${ }^{1}$ The slower uptake in DMEK's popularity has been attributed to current problems with DMEK, including the surgical challenges associated with manipulating the graft in the eye and higher rates of postoperative graft detachments. ${ }^{4}$ One of the challenges of graft manipulation includes the unfolding of the DMEK donor graft scroll in the anterior chamber. As a tight scroll can present a technical challenge during surgery, we herein seek to identify media and temperature conditions that could influence donor graft scroll widths.

\section{Materials and methods}

Ethical statement: Ten human donor tissue grafts were collected from the Keralink International Eye Bank, USA, for research purposes, with a written consent from each donor's next of kin. As our study used cadaveric donor tissues, the study was considered exempt from Institutional Review Board (IRB) review, per the University of Miami, Human Subject Office.

This study was a laboratory investigation. All of the DMEK grafts were "pre-stripped" and "pre-cut" by the same eye-bank technician within $48 \mathrm{~h}$ prior to the date of this study. The grafts were processed via the SCUBA (submerged cornea using backgrounds away) Descemet's peeling technique with a 1-2 mm central attachment remaining. Grafts were then punched to $8 \mathrm{~mm}$ via Coronet trephine and placed into a Bausch \& Lomb viewing chamber filled with Optisol-GS. The inclusion criteria for the DMEK grafts were 1) donors over 50 years of age and 2) without prior history of ocular surgery. We excluded all grafts below 50 years of age as well as grafts which tore during the "pre-stripping" or "pre-cutting" process. On the day of the study, the baseline cell count was taken via specular microscopy (Konan Medical, CellChek D+) for the donor corneas at room temperature $\left(20^{\circ} \mathrm{C}-25^{\circ} \mathrm{C}\right)$.

The endothelium sides of the donor corneas were stained with Trypan Blue Solution $0.4 \%$, for $30 \mathrm{~s}$, and the "pre-cut" DMEK donor grafts were carefully stripped with the McPherson tying forceps via a one-touch technique. The DMEK donor grafts were randomly assigned to three different groups of fluid media - three donor grafts were placed in petri-dishes containing Optisol ${ }^{\circledR}$ (Chiron Ophthalmics, Irvine, CA, USA), four were placed in petri-dishes containing Balanced Salt Solution (BSS; Alcon Laboratories, Fort Worth, TX, USA), and the remaining three were placed in petri-dishes containing BSS PLUS ${ }^{\circledR}$ (BSS Plus; Alcon Laboratories). The donor grafts were placed in the fluid media immediately following stripping. The DMEK donor grafts were then transferred

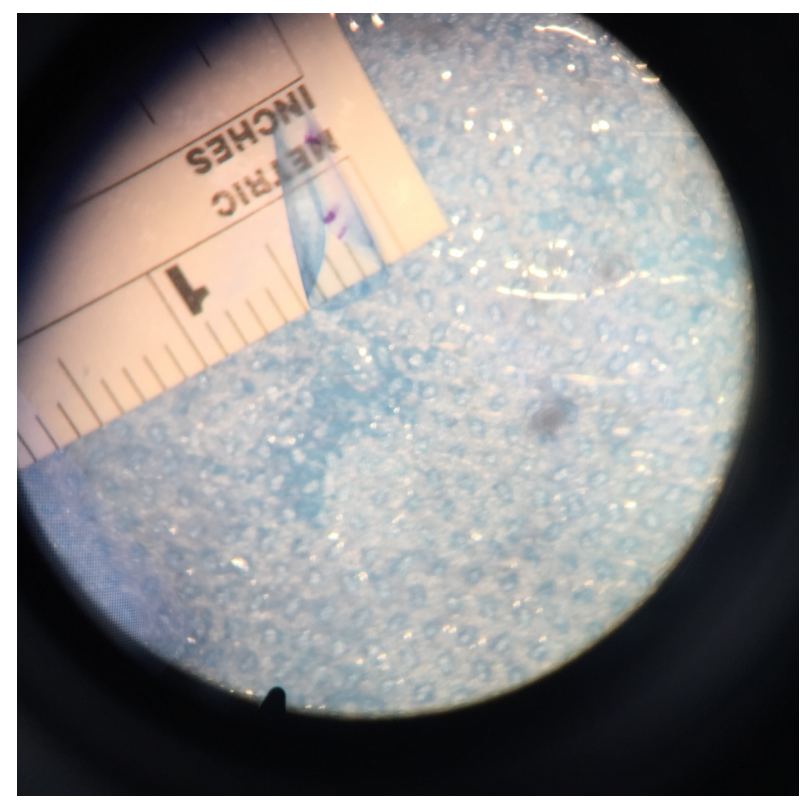

Figure I DMEK graft scroll width measurement. The DMEK donor graft is photographed free-floating in the petri-dish filled with media solution. The measuring ruler is used as a reference point.

Abbreviation: DMEK, Descemet's membrane endothelial keratoplasty.

to a laboratory refrigerator (Jewett JBB1204A22; ThermoScientific, Waltham, MA, USA), which could constantly maintain a cold temperature of $4^{\circ} \mathrm{C}$. The grafts remained in this cold environment for $60 \mathrm{~min}$. This time-frame was chosen in order to fully equilibrate the temperature of the media solution holding our grafts, to $4^{\circ} \mathrm{C}$.

At the end of the $60 \mathrm{~min}$, the donor grafts' scroll widths were examined and measured using ImageJ software (https:// imagej.nih.gov), and using the measuring ruler placed underneath the petri-dish as a reference point (Figure 1). The widest point of the scroll widths were measured. The donor grafts were then warmed in the laboratory incubator (Friocell 55; MMM Group, Munchen, Germany) and brought to physiological temperature $\left(35^{\circ} \mathrm{C}-37^{\circ} \mathrm{C}\right)$. The influence of temperature and solution was assessed statistically with mixed linear models (SPSS Statistics version 22; IBM Corporation, Armonk, NY, USA) to account for multiple measurements made on the same corneas. One sample of each donor corneas was assigned to each of the three temperatures to balance effects of age, sex, and baseline endothelial cell count.

\section{Results}

In 30 measurements of ten tissues (Table 1) across three temperature and fluid conditions, the average scroll width measured $1.73 \mathrm{~mm}$. The scroll widths ranged from 1.1 to $2.9 \mathrm{~mm}$ (Tables 2-4).

In a mixed linear model, scroll width size increased with temperature $(P=0.023)$. Age, sex, and baseline endothelial 
Table I Donor graft characteristics

\section{Donor characteristics}

Total number of grafts

Pair from same donor

Age range (years)

Sex (M:F)

Endothelial cell range

cell count were balanced with respect to temperature and, therefore, do not confound this result; however, in a multiple linear regression model, none were statistically significantly related to scroll width (all $P \geq 0.13$ ). In our small sample, we had limited ability to assess the importance of using two corneas from the same donor $(n=3)$; however, the intraclass correlation between the two eyes was 0.31 - that is, inclusion of right and left corneas from the same donor $(n=3)$ did not appear to contribute substantively to a more similar scroll width size.

There average scroll widths were $1.80,1.57$, and 1.86 for Optisol, BSS plus, and BSS, respectively. There was no significant difference in scroll width among the three solutions $(P=0.64$, mixed linear model).

\section{Discussion}

The DMEK surgical procedure was formally introduced as a surgical technique from 2002 to $2006 .^{6-8}$ This was a consequence of the evolution of the posterior lamellar keratoplasty (PLK) techniques, wherein the key concept is to replace the corneal endothelium with a suture-less posterior lamellar graft via a small incision. ${ }^{9-14}$

DMEK permits the transplantation of the Descemet's membrane and endothelium, without the additional posterior stroma as with other PLK (including DSEK) procedures. This, in turn, translates into better visual acuity results in the first year after surgery than reported for DSEK. ${ }^{4}$ The DMEK procedure was also found to have less postoperative refractive
Table 3 Cold temperature and scroll width

\begin{tabular}{lll}
\hline Conditions & Donor graft & Width $(\mathbf{m m})$ \\
\hline Optisol cold $\left(4^{\circ} \mathrm{C}\right)$ & $\mathrm{I}$ & $\mathrm{I} .687$ \\
Optisol cold $\left(4^{\circ} \mathrm{C}\right)$ & 2 & $\mathrm{I} .492$ \\
Optisol cold $\left(4^{\circ} \mathrm{C}\right)$ & 3 & $\mathrm{I} .546$ \\
BSS plus cold $\left(4^{\circ} \mathrm{C}\right)$ & 4 & $\mathrm{I} .1 \mathrm{I}$ \\
BSS plus cold $\left(4^{\circ} \mathrm{C}\right)$ & 5 & $\mathrm{I} .623$ \\
BSS plus cold $\left(4^{\circ} \mathrm{C}\right)$ & 6 & $\mathrm{I} .204$ \\
BSS plus cold $\left(4^{\circ} \mathrm{C}\right)$ & 7 & $\mathrm{I} .592$ \\
BSS cold $\left(4^{\circ} \mathrm{C}\right)$ & 8 & 1.928 \\
BSS cold $\left(4^{\circ} \mathrm{C}\right)$ & 9 & $1.48 \mathrm{I}$ \\
BSS cold $\left(4^{\circ} \mathrm{C}\right)$ & 10 & $\mathrm{I} .483$ \\
\hline
\end{tabular}

Abbreviation: BSS, Balanced Salt Solution.

changes and similar endothelial cell counts when compared to DSEK. ${ }^{4}$ In addition, DMEK had a significantly reduced rejection risk profile within 2 years after surgery, compared with DSEK and PK. ${ }^{5}$

However, despite these advantages, DSEK is still the most common endothelial keratoplasty procedure. ${ }^{1}$ The main challenge for the novice DMEK surgeon is the manipulation and the unfolding of the DMEK graft in the eye. ${ }^{4}$ Guerra et al have noted that the DMEK donor grafts from young donors ( $<30$ years) are more difficult to unfold, and younger donor tissues tend to scroll more tightly. ${ }^{4}$ Grafts from donors younger than 55 years are usually thinner and show pronounced scrolling; this is because the posterior nonbanded layer of Descemet's membrane gradually thickens with age. ${ }^{15}$ For this reason, donor selection should exclude donors under 50 years because of tissue elasticity, ${ }^{16}$ in order to avoid a tight scroll intraoperatively.

Keeping in mind this propensity of younger donor tissue for scrolling tightly, we used tissue from donors over 50 years of age (age range 51-69) for our study.

In regard to the finding of temperatures affecting scroll width size - we observed increased scroll widths with increased temperature $(P=0.023)$. A "wider" scroll may
Table 2 Room temperature and scroll width

\begin{tabular}{lll}
\hline Conditions & Donor graft & Width $(\mathbf{m m})$ \\
\hline Optisol room temp $\left(20^{\circ} \mathrm{C}-25^{\circ} \mathrm{C}\right)$ & $\mathrm{I}$ & 2.678 \\
Optisol room temp $\left(20^{\circ} \mathrm{C}-25^{\circ} \mathrm{C}\right)$ & 2 & 1.702 \\
Optisol room temp $\left(20^{\circ} \mathrm{C}-25^{\circ} \mathrm{C}\right)$ & 3 & 1.932 \\
BSS plus room temp $\left(20^{\circ} \mathrm{C}-25^{\circ} \mathrm{C}\right)$ & 4 & 2.583 \\
BSS plus room temp $\left(20^{\circ} \mathrm{C}-25^{\circ} \mathrm{C}\right)$ & 5 & 1.706 \\
BSS plus room temp $\left(20^{\circ} \mathrm{C}-25^{\circ} \mathrm{C}\right)$ & 6 & 1.554 \\
BSS room temp $\left(20^{\circ} \mathrm{C}-25^{\circ} \mathrm{C}\right)$ & 7 & 2.096 \\
BSS room temp $\left(20^{\circ} \mathrm{C}-25^{\circ} \mathrm{C}\right)$ & 8 & 1.957 \\
BSS room temp $\left(20^{\circ} \mathrm{C}-25^{\circ} \mathrm{C}\right)$ & 9 & 1.974 \\
BSS plus room temp $\left(20^{\circ} \mathrm{C}-25^{\circ} \mathrm{C}\right)$ & 10 & 2.91 \\
\hline
\end{tabular}

Abbreviation: BSS, Balanced Salt Solution.
Table 4 Warm temperature and scroll width

\begin{tabular}{lll}
\hline Conditions & Donor graft & Width $(\mathbf{m m})$ \\
\hline Optisol warmed $\left(35^{\circ} \mathrm{C}-37^{\circ} \mathrm{C}\right)$ & $\mathrm{I}$ & 1.532 \\
Optisol warmed $\left(35^{\circ} \mathrm{C}-37^{\circ} \mathrm{C}\right)$ & 2 & 1.745 \\
Optisol warmed $\left(35^{\circ} \mathrm{C}-37^{\circ} \mathrm{C}\right)$ & 3 & 1.867 \\
BSS plus warmed $\left(35^{\circ} \mathrm{C}-37^{\circ} \mathrm{C}\right)$ & 4 & 1.065 \\
BSS plus warmed $\left(35^{\circ} \mathrm{C}-37^{\circ} \mathrm{C}\right)$ & 5 & 1.499 \\
BSS plus warmed $\left(35^{\circ} \mathrm{C}-37^{\circ} \mathrm{C}\right)$ & 6 & 1.226 \\
BSS plus warmed $\left(35^{\circ} \mathrm{C}-37^{\circ} \mathrm{C}\right)$ & 7 & 1.743 \\
BSS warmed $\left(35^{\circ} \mathrm{C}-37^{\circ} \mathrm{C}\right)$ & 8 & 1.677 \\
BSS warmed $\left(35^{\circ} \mathrm{C}-37^{\circ} \mathrm{C}\right)$ & 9 & 1.717 \\
BSS warmed $\left(35^{\circ} \mathrm{C}-37^{\circ} \mathrm{C}\right)$ & 10 & 1.484 \\
\hline
\end{tabular}

Abbreviation: BSS, Balanced Salt Solution. 
translate into an easier and shorter surgery, as a tighter scroll demands more manipulation in order to "un-scroll" in the anterior chamber. This is of significant interest to the DMEK surgeon, especially the novice DMEK surgeon.

The storage media for the donor grafts had become a point of interest in the area of EK when Lee et al demonstrated that presoaking DSEK donor lenticules in BSS Plus reduces rates of DSEK graft detachment. ${ }^{17}$ More recently, with increased interest in the preloaded DMEK graft, ${ }^{18,19}$ the question remains as to which is the optimal solution to store the DMEK donor grafts in the preloaded systems. Although BSS Plus had the smallest average scroll width, our study did not demonstrate a significant difference among the solutions $(P=0.64)$. As aforementioned, a tight scroll poses a challenge intraoperatively, as it becomes more difficult to unfold. Our results suggest that, perhaps, the surgeon could consider avoiding BSS Plus when selecting a media agent to "pre-soak" the DMEK donor graft.

The main difference between BSS Plus and BSS is the presence of additional bicarbonate, phosphate, glucose, and glutathione. The $\mathrm{pH}$ of BSS Plus is 7.4, compared to 7.6 in BSS. The osmolality (mOsm) of BSS Plus is 305, compared to 298 for BSS. It is possible that the difference in $\mathrm{pH}$ or osmolality affects the scrolling behavior of the donor graft. Further studies would be warranted to elucidate the effects of $\mathrm{pH}$ and osmolality on scroll behavior.

The assignment of cornea samples to temperatures in our study was designed to eliminate the influence of donor characteristics on scroll width. Of the ten donor grafts, six of the donor grafts were pairs from three donors - that is, we obtained the right and left corneas from three donors. Our small study has very limited ability to assess the correlation of scroll widths between the two corneas of the same donor; however, we found that the right and left corneas from the same donor had a modest correlation of 0.31 .

The main weakness of this study is the small sample size. However, the $P$-value finding (0.023) of the observation of increased scroll widths with increased temperature signifies that, despite the small sample size, the $P$-value supports the significance of this correlation between temperature and scroll width.

The DMEK technique continues to evolve, and this surgical technique offers the potential to give the fastest and most complete visual recovery for endothelial disorders. ${ }^{20}$ The main finding of our study could potentially advance the DMEK technique - the increase in temperature effectively leads to a wider scroll width and, thus, would allow the DMEK surgeon to unfold the graft more easily.

\section{Acknowledgment}

This study was funded in part by the NIH Core Center Grant P30EY014801. KeraLink International provided donor tissue grafts and use of their facility for this study.

\section{Disclosure}

This scientific study was initiated by the principal investigators (Koo and Eghrari). The authors report no conflicts of interest in this work.

\section{References}

1. Park CY, Lee JK, Gore PK, Lim CY, Chuck RS. Keratoplasty in the United States: a 10-year review from 2005 through 2014. Ophthalmology. 2015;122(12):2432-2442.

2. Price MO, Price FW Jr. Endothelial keratoplasty - a review. Clin Exp Ophthalmol. 2010;38(2):128-140.

3. Lee WB, Jacobs DS, Musch DC, Kaufman SC, Reinhart WJ, Shtein RM. Descemet's stripping endothelial keratoplasty: safety and outcomes: a report by the American Academy of Ophthalmology. Ophthalmology. 2009;116(9):1818-1830.

4. Guerra FP, Anshu A, Price MO, Giebel AW, Price FW. Descemet's membrane endothelial keratoplasty: prospective study of 1-year visual outcomes, graft survival, and endothelial cell loss. Ophthalmology. 2011;118(12):2368-2373

5. Anshu A, Price MO, Price FW Jr. Risk of corneal transplant rejection significantly reduced with Descemet's membrane endothelial keratoplasty. Ophthalmology. 2012;119(3):536-540.

6. Eghrari AO, Gottsch JD. Fuchs' corneal dystrophy. Expert Rev Ophthalmol. 2010;5(2):147-159.

7. Melles GR, Lander F, Rietveld FJ. Transplantation of Descemet's membrane carrying viable endothelium through a small scleral incision. Cornea. 2002;21(4):415-418.

8. Melles GR, Ong TS, Ververs B, van der Wees J. Descemet membrane endothelial keratoplasty (DMEK). Cornea. 2006;25(8):987-990.

9. Melles GR. Posterior lamellar keratoplasty: DLEK to DSEK to DMEK. Cornea. 2006;25(8):879-881.

10. Terry MA, Ousley PJ. Deep lamellar endothelial keratoplasty in the first United States patients: early clinical results. Cornea. 2001;20(3): 239-243.

11. Melles GR, Lander F, Nieuwendaal C. Sutureless, posterior lamellar keratoplasty: a case report of a modified technique. Cornea. 2002;21(3): 325-327.

12. Terry MA, Ousley PJ. Small-incision deep lamellar endothelial keratoplasty (DLEK): six-month results in the first prospective clinical study. Cornea. 2005;24(1):59-65.

13. Melles GR, Kamminga N. Techniques for posterior lamellar keratoplasty through a scleral incision. Ophthalmologe. 2003;100(9):689-695. German [with English abstract].

14. Melles GR, Wijdh RH, Nieuwendaal CP. A technique to excise the Descemet membrane from a recipient cornea (descemetorhexis). Cornea. 2004;23(3):286-288.

15. Murphy C, Alvarado J, Juster R. Prenatal and postnatal growth of the human Descemet's membrane. Invest Ophthalmol Vis Sci. 1984;25(12): 1402-1415.

16. Kruse FE, Schrehardt US, Tourtas T. Optimizing outcomes with Descemet's membrane endothelial keratoplasty. Curr Opin Ophthalmol. 2014;25(4):325-334.

17. Lee JK, Eghrari AO, Desai NR, Stark WJ, Gottsch JD. Presoaking donor corneas reduces graft detachment rates in Descemet stripping endothelial keratoplasty. Am J Ophthalmol. 2009;147(3):439-441.

18. Parekh M, Ruzza A, Ferrari S, Busin M, Ponzin D. Preloaded tissues for Descemet membrane endothelial keratoplasty. Am J Ophthalmol. 2016;166:120-125. 
19. Knappschaftsklinikum Saar GmbH: Weltweit erste Hornhautgewebebank für Preloaded DMEK, Concept, Ophthalmologie, 4_2016.jpg. Available from: http://www.media-activa.de/media/content/2568/ media_160609161202.jpg. Accessed November 14, 2016.
20. Dapena I, Moutsouris K, Droutsas K, Ham L, van Dijk K, Melles GR. Standardized "no-touch" technique for Descemet membrane endothelial keratoplasty. Arch Ophthalmol. 2011;129(1):88-94.
Clinical Ophthalmology

\section{Publish your work in this journal}

Clinical Ophthalmology is an international, peer-reviewed journal covering all subspecialties within ophthalmology. Key topics include: Optometry; Visual science; Pharmacology and drug therapy in eye diseases; Basic Sciences; Primary and Secondary eye care; Patien Safety and Quality of Care Improvements. This journal is indexed on

Submit your manuscript here: http://www.dovepress.com/clinical-ophthalmology-journal

\section{Dovepress}

PubMed Central and CAS, and is the official journal of The Society of Clinical Ophthalmology (SCO). The manuscript management system is completely online and includes a very quick and fair peer-review system, which is all easy to use. Visit http://www.dovepress.com/ testimonials.php to read real quotes from published authors. 